\title{
The Falun Gong in China: A Sociological Perspective*
}

\author{
Cheris Shun-ching Chan
}

ABSTRACT This article offers a sociological perspective on the rise of and crackdown on the falun gong in relation to the social, cultural and political context of China. I specify from a sociological perspective that the falun gong is categorically not a sect but a cult-like new religious movement. Its popularity, I suggest, is related to the unresolved secular problems, normative breakdown and ideological vacuum in China in the 1980s and 1990s. Before the crackdown, the falun gong represented a successful new religious movement, from a Euro-American perspective. However, most of its strengths as a movement have become adversarial to its survival in the specific historical and political condition of China.

The phenomenal growth and overseas expansion of the falun gong (FLG; also known as the falun dafa) surprised the Chinese leadership. On the other hand, the heavy-handed crackdown launched by the Chinese government on this group startled world-wide observers. This article attempts to understand the rise and fall of the FLG from a sociological perspective. Applying theoretical insights from the sociology of new religious movements (NRM), it explores how the contemporary sociocultural context of China contributed to the popularity of religious and quasi-religious qigong movements like the FLG and why the Chinese government launched a severe crackdown on this particular group.

In the late 1980 s there were already many religious and quasi-religious qigong groups in mainland China. ${ }^{1}$ A sociological analysis of the popularity of the FLG will contribute to an understanding of the "qigong fever" phenomenon in China. The FLG was founded by a 47 -year-old Chinese man, Li Hongzhi, in Changchun in 1992 and spread rapidly first in north-eastern China and soon across the whole country. The number of FLG practitioners multiplied and reached millions within seven years. Between late 1998 and early 1999, the group reached its peak, with thousands of practice sites (liangong dian) scattered all over public parks in China. In the late 1990s, it expanded globally and had "main stations" (zongzhan) in numerous developed and developing countries.

David Ownby notes that anti-qigong voices were heard in China as early as the late 1980s. Criticism was centred on the pseudo-scientific

\footnotetext{
* Thanks to Hoiman Chan, Gary Fine, Wendy Griswold, Bobai Li, Stephen Warner and Dingxin Zhao for useful comments on earlier versions of this article.

1. Sima Nan, an anti-quasi-religious qigong critic in China, said that the FLG was not the largest qigong group. He listed several others such as zhong gong, yuan ji gong and wang gong, all of which were said to be larger than the FLG in terms of its membership, though no proof was given. See "A star turn for China's cult buster," The New York Times, 22 November 1999.
}

(C) The China Quarterly, 2004 
claims made by the qigong masters. ${ }^{2}$ Nevertheless, the Chinese authorities did not take any serious action against qigong groups before the mid-1990s. ${ }^{3}$ In fact, the $F L G$ was once recognized by the Chinese authorities as contributing to the improvement of the health of thousands of middle-aged and older citizens. ${ }^{4}$ To the surprise of FLG practitioners and observers within and outside China, the Chinese government outlawed the group on 22 July 1999 and rounded up more than 5,000 followers within a week. The mass sit-in held by FLG followers outside the Chinese Communist Party (CCP) leaders' residence in Zhongnanhai, Beijing, on 25 April 1999 seems to be the incident that was the immediate cause of the suppression. Some scholars suggest that the provocative behaviour of the charismatic leader and his followers led the Chinese authorities to believe that the FLG could threaten social stability and challenge their rule. ${ }^{5}$ Nevertheless, the collective actions taken by FLG followers were all sit-in petitions in a well-disciplined and rule-observing manner. They can hardly be described as provocative in themselves. Why, then, did the Chinese authorities launch such a heavy-handed crackdown against the group?

This article addresses three issues of the FLG. In view of the popular labelling of the group as a sect and a cult, it first delineates its sociological nature based on the NRM literature. I suggest that the FLG can be understood as a NRM with characteristics comparable to those in EuroAmerican contexts in the 1950 s to 1970 s. It is less a sectarian than a cult-like NRM. It emerged as a response to the unresolved secular problems and normative breakdown brought about by the dramatic economic reforms and the ideological vacuum left by the decline of the communist ideology. The popular accounts of the crackdown on the FLG are often one-sided, attributing the problem either to the behaviour of the group or to an internal crisis within the CCP. I argue that neither of these can be a sufficient factor. Instead, it is the interaction among the political implication of Chinese history of NRMs, the social canon of social stability since 1989 , the organizational nature and mobilization power of the $F L G$, the strong ideological commitment of $F L G$ followers and the

2. David Ownby, “' 'Heterodoxy' in late socialist China: the Chinese state's case against Falungong," paper presented at the East Asian Workshop at University of Chicago, 27 March 2001, pp. 11-12.

3. The regime's first campaign against some qigong practices came in February 1996 when a qigong organization called Shen Chang Center for Human Body Applied Science and Technology in Suzhou was fined 8 million RMB. The use of qigong for healing was prohibited but there was no severe national crackdown on a particular qigong group before the one on the FLG. See James Tong, "An organizational analysis of the falun gong: structure, communications, financing," The China Quarterly, No. 171 (September 2002), p. 640.

4. For example, Li Hongzhi was honoured with "The award for advancing boundary science" by the Committee of Specialists of the Oriental Health Expo in China in 1993, according to a $F L G$ website called Minghui Net (Clear Wisdom Net) at www.clearwisdom.ca. See also Zhang Weiqing and Qiao Gong, Li Hongzhi pingchuan: falun gong chuangshiren (Comments on and the Biography of Li Hongzhi: The Founder of Falun Gong) (Hong Kong: Mirror Books, 1999).

5. See, for example, John Wong, "The mystery of Falun Gong: its rise and fall in China," EAI Background Brief, No. 39 (Singapore: East Asian Institute National University of Singapore, 1999). 
overseas support of the FLG leader that led to the strong-handed crackdown against the group. Borrowing sociologist Rodney Stark's "model of success" for NRMs, I find that two of the criteria for success in the American context, namely effective mobilization and internal network, ironically put the FLG at stake in the Chinese historical and political context.

\section{Methods and Data}

This article relies mainly on four sources of information: my year-long ethnographic research on the FLG in Chicago and Hong Kong from June 1999 to July 2000; FLG publications such as books, audio and video tapes, and articles from FLG official and associated websites; Chinese government official propaganda materials such as video tapes, books and the press; and media reports in the United States and Hong Kong.

I began my ethnographic study of the FLG in Chicago in June 1999 by being a practitioner. ${ }^{6}$ I joined different kinds of $F L G$ practices, gatherings and activities in Chicago on a regular basis for six months from August 1999 to January 2000. From February to July 2000, my participation was more focused and selective. I participated less in their regular weekly practices but more in their monthly events and special activities. ${ }^{7} \mathrm{My}$ research in Hong Kong was divided into two periods. The first lasted for three weeks from the middle of July to early August 1999, during which I conducted intensive participant observation and joined $F L G$ activities almost every day. ${ }^{8}$ I kept in regular contact with some followers in Hong

6. My role as a researcher was made clear to the key informants. The attitude of the followers in Chicago toward my research was open and helpful. They treated me as an ordinary follower, which was what I attempted to maintain as my participant identity. Patricia and Peter Adler have discussed in detail the advantages and drawbacks of various kinds of membership roles in ethnographic research. My role in the FLG lies in between a periphery and an active membership. My moderately active membership role enabled me to experience the subjectivities of the group yet maintain a distance at times for objective analysis. It also allowed me to collect data in a relatively natural environment and get access to some information that cannot be obtained from formal interviews. Nevertheless, the significant drawbacks of an active membership are role conflict and the feeling of betraying the informants. During the second half of my research period, my role was more a periphery one. The periphery role permitted me to maintain a more objective analysis and minimized the role conflict. See Patricia and Peter Adler, Membership Roles in Field Research (CA: Sage Publications, 1987).

7. My selective participation was a deliberate move for two reasons. First, the FLG followers had increasingly identified me as one of them and asked me to help to set up a practice site at my school, Northwestern University. My decreasing participation in the regular practices helped to clarify my role as a researcher, apart from being a FLG practitioner. Secondly, the regular practices of the $F L G$, which include a set of qigong exercise, standing and sitting mediations, and reading the Zhuan falun, are rather standardized. Prolonged observation of these practices seemed unnecessary. Most dynamic interactions and discourses among the followers took place during the relatively large-scale monthly events or special gatherings like protests, promoting the $F L G$ and partying.

8. Some followers in Hong Kong welcomed my research on them whereas some others were sceptical. I dealt with the scepticism by assuring them of the research ethics of confidentiality and anonymity and explaining to them what a sociological perspective is. However, one of the core followers commented that the FLG was too sacred to be analysed from an academic perspective which he worried would distort the "true nature" of the FLG. 
Kong through electronic mail when I was in Chicago. In December 1999, I visited Hong Kong again and conducted another three-week intensive research on the group.

Informal interviews through casual conversations were done during participant observation. In addition, I conducted 29 face-to-face interviews that lasted from one-and-a-half to three hours. Ten were done in Hong Kong and 19 in Chicago. Twelve of the interviewees are "core followers," ten are "ordinary followers" and seven are "peripheral practitioners" (see the next section for the distinctions of these membership categories). There are 16 females and 13 males, with ages ranging from 23 to 69 .

I was not able to conduct field research in China during my research period, but I interviewed a number of Chinese followers who had immigrated to or visited Chicago or Hong Kong after the crackdown. Eleven interviewees were either new immigrants or visitors in Chicago or Hong Kong, and were the key informants for my data of the FLG in China. This method of extrapolating from relevant information collected outside China to China was used by anthropologists when they had no access to mainland China in the early decades of communist rule. ${ }^{9}$ Two acknowledged limitations of this method are, first, the incomplete representativeness of the interviewees and, secondly, the contextual problem of my observation. The interviewees in Chicago and Hong Kong are likely to be different from the ordinary FLG practitioners in mainland China. For example, they are usually better educated and economically better off than the majority of the practitioners in China. The societal contexts of Chicago and Hong Kong are undeniably different from that of China. The measures I took to minimize the problems include: asking the interviewees to describe what happened to their fellow practitioners in their practice sites apart from narrating their own experiences; interviewing a few non-FLG Chinese in Chicago who had witnessed the FLG phenomenon and the crackdown in China; and cross-checking my ethnographic data with writings from followers in mainland China and information from the media. Thus, my analysis attempts to arrive at a plausible sociological explanation of the $F L G$ phenomenon and the crackdown based on the available data, rather than claiming a perfect representation of the FLG and the responses of the CCP.

footnote continued

This is understandable and happens quite often to ethnographic research on religious groups when the researchers do not adopt a "pro-religion" bias. See Thomas Robbins' discussion of the ethical dilemma the sociologists of religion face between sympathy and objectivity in studying religions in Cult, Converts and Charisma: The Sociology of New Religious Movement (London: Sage Publications, 1988), pp. 199-204.

9. Hong Kong and Taiwan were commonly the locations for research and findings were projected to mainland China with caution. See, for example, Jack Potter, Capitalism and the Chinese Peasant (Berkeley: University of California Press, 1968) and Hugh Baker, A Chinese Lineage Village: Sheung Shui (Stanford: Stanford University Press, 1968). 
The Falun Gong as a New Religious Movement

Definitions of new religious movement, sect and cult. Despite the diversity of the NRMs in Euro-American societies, a few common characteristics can be identified. A NRM is usually led by a charismatic leader who is accepted by her or his followers as having final authority in both spiritual and material matters. She or he is regarded as a representative of some sacred power and is obeyed accordingly. ${ }^{10}$ The usual form of organization tends to be a conjoining of modern, rational methods with inspirational and charismatic content. ${ }^{11}$ According to Eileen Barker, most NRMs have different "layers" of membership, ranging from full-time and committed members, to active followers, to marginal participants. ${ }^{12}$ The sacred beliefs and practices of the NRMs are eclectic and mostly inward-oriented. Members are enthusiastically and passionately involved. Meditation is common, and cure of personal ills, resolution of problems and improvement in mental and psychological well-being are commonly reported from the practitioners. ${ }^{13}$

Most of the NRMs in Euro-American contexts belong to the category of sect or cult. Sociologically, these are distinguishable in terms of their belief content, organizational structure and relation to society. While the term "cult" in popular usage bears some derogatory connotations, the nature of a cult is less anti-social and exclusive than that of a sect. ${ }^{14} \mathrm{~A}$ sect normally has a prior theological tie with another religious organization, mainly the Judeo-Christian church in the Western context. ${ }^{15}$ Its organizational characteristics include exclusive membership, communal and cohesive structure, high demands on members' spiritual perfection and expulsion of those who do not follow the moral precepts. The demanding spiritual and organizational characteristics of a sect tend to steer it away from secular society, often making it appear hostile or indifferent. ${ }^{16} \mathrm{~A}$ cult, on the other hand, does not have a prior theological

10. John Saliba, Understanding New Religious Movements (Michigan: William B. Eerdmans Publishing Co., 1995), pp. 12-13.

11. Bryan Wilson, "Factors in the failure of the new religious movements," in David Bromley and Phillip Hammond (eds.), The Future of New Religious Movements (Georgia: Mercer University Press, 1987), p. 36.

12. Eileen Barker, New Religious Movements: A Practical Introduction (London: HM Stationery Office, 1989), pp. 11-15.

13. Saliba, Understanding New Religious Movements, pp.18-20.

14. After the massive suicides and five murders committed by People's Temple in Guyana in the United States in November 1978, the term "cult" has become associated not only with danger to the followers but also physical threats to society at large. The anti-cult movement has intensified since then. See Eileen Barker, "Religious movements: cult and anticult since Jonestown," Annual Review of Sociology, Vol. 12 (1986), pp. 329-346.

15. Rodney Stark and William Bainbridge, "Of churches, sects, and cults: preliminary concepts for a theory of religious movements," Journal for the Scientific Study of Religion, Vol. 18, No. 2 (1979), pp. 117-133.

16. Ibid.; see also Bryan Wilson, "An analysis of sect development," American Sociological Review, (February 1959), pp. 3-15; Colin Campbell, "The cult, cultic milieu and secularization," A Sociological Yearbook of Religion in Britain, Vol. 5 (1972), pp. 119-136; Roy Wallis, "Scientology: therapeutic cult to religious sect," Sociology, Vol. 9, No. 1 (1975), pp. 89-100. 
tie with an established religious body ${ }^{17}$ Its beliefs and practice are very often mystically and individualistically oriented. ${ }^{18}$ Cults are usually loosely structured with a fluctuating membership and tolerant of other organizations and faiths. ${ }^{19}$ However, as their belief content is predominantly based on Asian religions or philosophies such as Buddhism, Hinduism and lesser-known Indian beliefs, they are perceived as deviant and anti-social in rationalized Western contexts.

In the case of the $F L G$, the Chinese authorities define it as an "evil religion" (xiejiao).$^{20}$ The press in Hong Kong and the United States describe it as a "sect" or occasionally a "cult." 21 On the other hand, the leader of the $F L G$ and his followers reiterate that the $F L G$ is neither a religion nor an organization. So, what is the nature of the $F L G$ from a sociological perspective?

The characteristics of the FLG. The founder of the FLG, Li Hongzhi, claims to be a saviour whose mission is the same as that of Jesus and Buddha. Li implies his supernatural power in the Zhuan falun. Accordingly, he would install "a complete system of cultivation practice" in followers' bodies in order to bring them to "higher levels." 22 FLG followers believe that $\mathrm{Li}$ has supernatural qualities. Miracle stories of how $\mathrm{Li}$ transcends the ordinary world by curing non-curable diseases and saving followers from dangerous situations have been narrated and circulated repeatedly among his followers. ${ }^{23}$ The portrayed characteristics of Li Hongzhi resemble other charismatic leaders of the NRMs.

The belief system and spiritual practices of the $F L G$ are an eclectic mixture of Buddhism, Daoism, Confucianism and the qigong tradition. Human life is believed to be created in the space of the universe, not in ordinary human society. A higher order of reality, invisible and beyond the reach of secular science, is believed to exist in the universe. The Zhuan falun, which was produced by Li's early followers from the transcription of his lectures in China, is regarded as a sacred text, a revelation of the Truth of the universe, the Truth being truthfulnessbenevolence-forbearance (zhen-shan-ren).

17. Stark and Bainbridge, "Of churches, sects, and cults," p. 125.

18. James Richardson, "An oppositional and general conceptualization of cult," The Annual Review of the Social Science of Religion, Vol. 2 (1978), pp. 29-51.

19. Campbell, "The cult," p. 121; Wallis, "Scientology," p. 91.

20. The translation of "xiejiao" can be "evil religion" or "evil teaching." However, the Chinese authorities use the word "cult" as an English translation of "xiejiao." Translating "xiejiao" into "cult" is inappropriate and unsupported by empirical facts. Literally, the word "cult" is not associated with any meanings of "evilness" in either Longman or Oxford English-Chinese Dictionaries.

21. Just to cite a few examples from The New York Times in the United States and South China Morning Post in Hong Kong: "The sect that became an enemy of the state," The New York Times, 25 July 1999, "Dozens more from sect arrested in Beijing," The New York Times, 30 October 1999, "20 sect followers arrested," South China Morning Post, 22 September 1999, and "Tiananmen police grab sect suspects," South China Morning Post, 30 September 1999.

22. Zhuan falun, pp. 1-7.

23. From my ethnographic observation. 
Followers believe that the FLG provides a path to salvation through elevating their moral quality or mind nature (xinxing), which is done by accumulating virtue ( $j i \mathrm{de}$ ) and eliminating bad karma (xiao ye). Practically, acting morally and bearing suffering accumulate virtues and eliminate bad karma at the same time. Modifying the Buddhist idea, the Zhuan falun states that illnesses and tribulations are repaying the debt of bad karma and, therefore, have a positive function. Medical treatment would only hamper one's path to enlightenment:

Nobody can casually change it (ye). Changing it will mean that one does not have to repay the debt after being in debt.... Some people think that treating patients, healing their illnesses, as well as keep them fit are good deeds. In my opinion, they have not really cured the illnesses. They have postponed or transformed them instead of removing them. ${ }^{24}$

Most of the core followers I interviewed reported their resistance to seek medical treatment when they were ill. For example, a young female follower in Hong Kong once suffered from a hurtful abdominal pain but refused to seek any medical treatment. She believed that the pain was a blessing bestowed by Master Li to remove part of her bad karma. ${ }^{25}$

$F L G$ practitioners range in age from 20 to over 70 years old, with middle-aged and elderly people in the majority. About 60 per cent of them are women. ${ }^{26}$ Young educated followers such as professors and graduate students are also found. Although the FLG does use the internet to circulate news and activities, the recruitment of new practitioners in China is mainly by word-of-mouth through family members, relatives, colleagues and friends. ${ }^{27}$

The membership of the FLG can be broadly divided into three categories based on the degree of commitment to the group. The core layer is composed of those who totally believe in the charismatic leader, his supernatural power and worldview, who read the Zhuan falun and

24. It is quoted from the English version of the Zhuan falun, p.3. To keep its originality, I have not attempted to correct any of the grammatical errors in this and the other quotations from the book.

25. The follower told me this incident in an interview. Another follower told me that she refused to go to hospital after she was hit by an car when crossing the road. She had the same interpretation that her suffering was indeed a blessing.

26. Zong Hairen, "Handling the falungong case," Chinese Law and Government, Vol. 35 No. 1 (January-February 2002), p. 64. This article is a chapter of a book called Zhu Rongji 1999, published in English in January 2001 and in Chinese in April 2001. Zong Hairen is the pseudonym of the author or a group of authors. According to the editorial note of Chinese Law and Government, Zhu Rongji 1999 was published with a similar aim to The Tiananmen Papers, mainly to provide the outside world with first-hand information of the internal dynamics of the CCP leadership and to discredit the General Secretary of the CCP, Jiang Zemin. It is believed to be a product of a person or persons with high-level access in Zhongnanhai, who belong to the reformist wing of the Party. See Andrew Nathan, "Guest editor's introduction," in the same issue of Chinese Law and Government, pp. 3-13. Despite its politically-biased objective, Zong's article seems to base on considerable factual information. Occasionally, the author raises some evaluative questions and presents judgmental statements about Jiang Zemin. In citing this article, I have been cautious not to refer to the judgmental statements but only to some figures and verbatim data.

27. According to three FLG followers who left Beijing for Chicago or Hong Kong after the crackdown and two non-FLG informants who came from Beijing. 
practise the qigong exercises almost every day. The ultimate concern of these core followers is to improve their moral quality or mind nature so that they can transcend the secular world to arrive at the "higher levels." At the other extreme is a peripheral layer. Strictly speaking, people in this layer are only practitioners, not followers. I call them peripheral practitioners. They do not care too much about the belief or the philosophy of the FLG but regard it as one of the many qigong practices and are attracted to it because it is simple and free of charge. An intermediate stratum between the core and the periphery is comprised of those who are committed to the $F L G$ to a certain degree: ordinary followers. They practise the FLG for both physical and moral improvement, read the Zhuan falun on a regular basis but occasionally raise doubts about Li's worldview and the possibility of salvation. ${ }^{28}$ These layered degrees of commitment agree with Eileen Barker's description of the membership characteristics of NRMs.

In terms of organization, there are two opposing versions. The Chinese government claims that the $F L G$ was a tightly organized, hierarchically structured organization. The $F L G$, on the other hand, says that it was not an organization as it had no physical establishment, no staff and no administrative structure. ${ }^{29}$ These two versions were both true to some extent at different times. As James Tong documents, the FLG made an organizational switch from more to less structured in early 1997 . With the official campaign against the use of qigong for healing and the failure of the FLG's attempt to obtain legal status in 1996, it abolished some of its organizational infrastructure in 1997. For instance, it disconnected telephones, abrogated the position of liaison officer, terminated its functional offices of translation, and discontinued services of purchasing FLG publications for practitioners. ${ }^{30}$

Nevertheless, the FLG was not without any organization after 1997. It was composed of a vertical point-to-point connection and two horizontal networks. The former refers to the connection among the informal leaders of practice sites (liangong dian), guidance stations (fudao zhan), branch stations (fenzhan) and main stations (zongzhan). Before the crackdown, each city or town had a number of practice sites for the convenience of the practitioners. A group of practice sites constituted a guidance station, several guidance stations made up a branch station, and several branch stations made up a main station at city or provincial level. Leaders of the practice sites and guidance stations were called counsellors (fudao yuan), and leaders of the branch stations and main stations were called the station head (zhan zhang). Most counsellors were either self-appointed or asked by local practitioners to volunteer. On the other hand, both the station heads in Hong Kong and Chicago were delegated by the charismatic leader. ${ }^{31}$

28. Information on the characteristics and commitment of the membership is both from my field observation and from three followers who came to Chicago from Beijing and Guangzhou after the crackdown.

29. James Tong noted these two opposing versions of the FLG organization. See Tong, "An organizational analysis," pp. 637-38.

30. Ibid. pp. 641-42.

31. From my field observation and interviews. 
The world-wide $F L G$ main stations were all horizontally linked to each other through the official falun dafa website, which was also used by the charismatic leader to convey messages and instructions to followers. Another horizontal organization was the interpersonal networks of the $F L G$ practitioners. The number of practitioners in a practice site in China ranged from 30 to more than 100. Practitioners within a site did not necessarily know each other and rarely interacted with practitioners from another site. ${ }^{32}$ However, as most joined the $F L G$ through their personal connections, they had pre-existing social relations. Such relations are close and in small discrete groups.

The organization of the $F L G$, however, was informal and quite loose after its switch in 1997. It did not have any staff or distinct administrative body. Practitioners paid no fees for joining the group and the practices. Anyone could attend the practice sites in public parks to learn the meditation and qigong exercises. No personal information needed to be disclosed. There was no formal or obvious informal enforcement to staying with the group. ${ }^{33}$

The FLG as a cult-like NRM. The characteristics of the FLG, to a large extent, meet the criteria of a NRM. It was formed in a period of dramatic social, economic and cultural change in China. Its followers are all new converts and most are without any previous religious experiences. The $F L G$ is "religious" as it holds a sacred worldview with supernatural beliefs. It is also a "movement," with its enthusiasm and efforts to re-establish moral ethics and normative guidance for its followers. Collective changes are observable in followers' moral standards, emotional states, behavioural ethos and physical health. ${ }^{34}$ Under the rubric of NRMs, is the FLG a sect, a cult or neither?

My empirical findings show that the $F L G$ is categorically not a sect nor is it precisely a cult. However, its organization and relation to society, as well as part of its belief content, have marked resemblance to those of a cult in a sociological definition.

The FLG was founded by a charismatic leader whose authority is absolute. The charismatic leader has created a set of sacred texts that are distinct from that of the traditional world religions. Although FLG followers are connected through both vertical and horizontal networks, organization at the levels of ordinary followers and periphery practi-

32. From my field observation and according to the FLG followers who came to Chicago and went to Hong Kong from China.

33. Information is derived from my observation in Chicago and in Hong Kong as well as my interviews with the non-FLG Chinese who had some acquaintance with the FLG in China. For some irregularities and regional variations of the FLG structure in China, see Tong, "An organizational analysis," pp. 642-46.

34. For more details about how FLG ideology affects the thoughts and behaviour of followers, see Cheris Shun-ching Chan, "We have to clear away the cloud': ideological commitment, collective discourses, and movement mobilization of the Falun Gong," paper presented at the 96th Annual Meeting of the American Sociological Association in August 2001 in Anaheim, California. 
tioners is loose and dispersed. The periphery practitioners make up the majority and their membership fluctuates widely. The founder claimed that the world-wide number of $F L G$ practitioners was 100 million. ${ }^{35}$ The Chinese authorities estimated that China had at least 2 to 3 million $F L G$ practitioners but the number could possibly be up to 40 million. ${ }^{36}$ The actual number is in dispute, and probably not even known by the charismatic leader. Despite its speedy growth, the $F L G$ did not attempt to replace other established religions, nor did it require the followers to relinquish their secular life. FLG followers keep their worldly jobs, live with their families and interact with non-FLG people in their daily life. Thus, the $F L G$ is cult-like in terms of its structure and relation to society.

Nevertheless, the FLG is not a cult per se. Although it does not have prior ties with any religious organizations and it holds some unorthodox philosophies, it has borrowed some religious content and moral maxims from Buddhist and Confucian teachings. In this sense, it is comparable to a sect. Thus, the FLG in the Chinese context at best can be categorized as a NRM with cult-like characteristics. Owing to the different sociological connotations of a sect and a cult, mislabelling the group is undesirable for understanding its socio-cultural implications.

\section{The Socio-Cultural Context in China and the Rise of the Falun Gong}

Two of the sociological explanations for the emergence of NRMs in the Euro-American context are useful for understanding the case in China. The normative breakdown theory argues that modernity has created a "normative dislocation" and "moral disturbance" under which new ideological forms are likely to emerge. NRMs are seen as "meaning seeking" and "moral re-establishing" movements. ${ }^{37}$ Another explanation attributes them to the unresolved problems of malfunctioning consumerism, inflation, break-up of breadwinner families, fear of crime and feeling of isolation. Losing faith in political and economic institutions in removing the problems, people direct their commitment to religious bodies for spiritual salvation. ${ }^{38}$

In China, the practices of qigong grew rapidly from the second half of the 1980s. In the early 1990s, the number of qigong groups, both registered and non-registered, reached about 2,000 and a "qigong fever" phenomenon was evident. ${ }^{39}$ Qigong is not new to Chinese society. Nevertheless, a common characteristic among the qigong groups that emerged in the last two decades is their religious or spiritual undertones.

35. "Falun fofa" ("Falun Buddhist method"), Ming Pao [Ming bao], 11 May 1999.

36. Zhang and Qiao, Comments on and the Biography of Li Hongzhi, p. 132.

37. Robert Bellah, "New religious consciousness and the crisis in modernity," in Charles Glock and Robert Bellah (eds.), The New Religious Consciousness (Berkeley: University of California Press, 1976), pp. 333-352.

38. Marvin Harris, America Now: The Anthropology of a Changing Culture (New York: Touchstone, 1981), pp. 141-165.

39. Zhang and Qiao, Comments on and the Biography of Li Hongzhi, p. 79; see also Ownby, " 'Heterodoxy." " 
Most are cult-like in their structure and practices. The popularity of the religious and quasi-religious qigong has formed a subculture of occult and spiritualism. The FLG emerged in 1992, as part and parcel of the "qigong fever" phenomenon. How can the rise and popularity of the religious and quasi-religious qigong movements in China be explained? The discussion below focuses on the $F L G$ but its relevance is not limited to this case.

Unresolved secular problems. Deng Xiaoping's daring and large-scale economic reforms brought about impressive economic growth. This, however, escalated unresolved social problems. Unemployment rates multiplied with the collapse of the state industries. The proportion of people falling below the poverty line decreased only slightly. ${ }^{40}$ At the same time, the distribution of income has been increasingly unequal between urban and rural areas and among different social groups within the urban population. The Gini coefficient of urban income inequality rose considerably after 1984 . In 1990 , it stood at 0.180 , almost back to the pre-reform level. ${ }^{41}$

Increasing income inequality is accompanied by a nation-wide shrinking of welfare. Especially marked is the commercialization of medical care, which had been provided practically free under the socialist system. One FLG representative explained to Zhu Rongji why they joined the $F L G$ :

Our work units no longer reimburse us for the payments we make for medical treatment and medicines, whereas Falungong can strengthen our physiques and improve our health. ${ }^{42}$

In her study of urban spaces in China, Nancy Chen finds that many urban dwellers were pulled to qigong practices as a communal alternative to the trend of intensified individual consumption and unequal access to health care. $^{43}$

My findings partly agree with Nancy Chen's observation. Many of the periphery practitioners joined the FLG simply for the qigong exercises and for improving their health. ${ }^{44}$ One of the reasons for FLG's unprecedented growth within a short time was that qigong classes were initially at a modest charge and later free: in 1993, only 10 to 50 yuan (approximately US\$1.2 to 6) while other qigong groups charged 100 to 200 yuan

40. Lucian Pye, "An overview of 50 years of the People's Republic of China: some progress, but big problems remain," The China Quarterly, No. 159 (September 1999).

41. The Gini coefficient is used for measuring income inequality. The index ranges between zero and one. The higher the index, the higher the inequality of income distribution. See Chai, "Consumption and living standards," pp. 737-740.

42. Zong Hairen, "Handling the falungong case," p.64.

43. Nancy Chen, "Health, wealth, and the good life," in Nancy Chen et al. (eds.), China Urban (Durham: Duke University Press, 2001), pp. 165-182.

44. To be fair, the Chinese have longed been aware of keeping themselves healthy through qigong exercises. It is difficult to assess the extent to which the medical reform has plunged people into various qigong practices. Nevertheless, the FLG reached its peak in 1998-99 when the State Council started to launch a nation-wide health insurance reform. 
(US\$12 to 24). ${ }^{45}$ Even some of the core followers admitted that they first joined the FLG simply because it might improve their health and was free of charge.

Normative breakdown. A devoted FLG follower who had joined other quasi-religious qigong groups before explained why the FLG is most appealing to her and able to keep up her faith:

Other qigong I joined before also taught us the importance of de (virtue). However, they didn't set a high standard for us to follow, nor did they make a real moral demand on our daily behaviour. The $F L G$ is different. It places the xinxing as the highest priority in life.... It requires us to follow the principle of zhen-shan-ren in our daily life.

Almost all the core followers I interviewed, notwithstanding the variation of their initial motives for joining the $F L G$, state that it was its moral teachings that make it superior to other qigong groups, in the context of a perceived decline of morality in China. In the words of a committed young follower from Beijing:

Lying, cheating, stealing, bribery, gambling, sex, divorce, fighting, kidnapping, murdering ... anything immoral and criminal you can think of are all happening in China. Whatever you can think of that is opposite to the Confucian teachings can be seen in China. If someone is lying on the street desperately asking for help, the onlookers would ask, "How much would you pay me to help you?"

The FLG selectively restates some of the virtues of the Buddhist and Confucian ethics and underscores the importance of truthfulness, benevolence and forbearance. The charismatic leader strongly condemns the loss of moral standards in the Zhuan falun:

The human moral standard is declining tremendously, and the human moral values are deteriorating daily. People only seek after interest and will harm others for a tiny bit of personal interest. They compete and struggle against each other by resorting to all means. Please think about it? Will this be allowed to continue ${ }^{46}$

The normative values of honesty, kindness and endurance have long been part of Confucian teachings. As Raymond Williams observes, when the dominant culture under-values or opposes the meanings and values which were created in the past but still have some significance in the present human experience, there is a "reaching back" to those meanings and values. ${ }^{47} \mathrm{~A}$ restatement of various moral standards and normative rules is apparently a reaching back to part of the traditional Chinese values that are under-recognized in contemporary social milieus. The

45. Information is cited from a TV programme "Falun gong daqidi" ("Revealing the reality of the falun gong") broadcast by the Fenghuang tai (Phoenix Channel) in China on 25-26 July 1999. This programme was part of the governmental propaganda against the FLG. Its content, nevertheless, was relatively objective and informative.

46. Quote directly from the English version of the Zhuan falun, p. 15.

47. Raymond Williams, Problems in Materialism and Culture (London: Verso, 1980), p. 42. 
$F L G$ is appealing to many people who find the current social order anomic. $^{48}$

Ideological vacuum. Although China still maintains a socialist political system and upholds some communist slogans, its economic and social orders, in effect, are capitalist. Radical marketization and commercialization have pushed the ideology of communism out of relevance to everyday life. The ideological vacuum left by the downfall of communism began to surface in the second half of the 1980s. The aftermath of the 4 June 1989 incident further shattered any idealistic ideology.

When communism was still an ideology for the Chinese, it served the same functions as religions do by providing meaning and hope for everyday life. With the collapse of such an ideology, people began seeking answers from pure science or religion. Science signifies modernity; whereas religion signifies superstition and backwardness. This is one of the reasons why the FLG refuses to identify itself as a religion. Nevertheless, most of its followers are drawn to it because of its spiritual aspirations and its ultimate answers to the meaning of life.

A young follower, a PhD student of chemistry, is pleased that he has found the ultimate answer to human life from the FLG:

The more you know about science, the more you know about its limitations in giving us answers. Where do human beings come from? Where do human beings go? What is the meaning of life? What is the goal of my life? Science cannot give you the answers. But the falun gong can.

This corresponds with Max Weber's hypothesis that a disenchantment of the world would eventually be followed by a re-enchantment when scientism fails to provide an ultimate answer for the meaning of life. ${ }^{49}$ With the suppression of religious freedom under communist rule for 50 years, it is not surprising to see hunger for religious or spiritual experience once the communist ideaology began fading away. The $F L G$ and other quasi-religious groups offer a sort of ecstatic religious and spiritual experience for the meaning-seekers in China.

\section{The Crackdown on the Falun Gong: Whose Fault?}

In spite of the meteoric rise of the FLG, the CCP's heavy-handed crackdown sent it into decline in China, at least for the time being. Although individual and small group resistant actions were seen in Beijing throughout the year after the crackdown, the $F L G$ has failed to obtain the political goals it set for mass petitions.

Rodney Stark theorizes "a model of success" for NRMs. A NRM is likely to succeed if it fulfils the following eight criteria: retaining

48. For a classical sociological theory of anomie, see Emile Durkheim, "Anomic suicide," in Suicide: A Study in Sociology (New York: The Free Press, 1951), pp. 241-276. See also Robert Merton, "Social structure and anomie," in Social Theory and Social Structure (New York: The Free Press, 1968), pp. 185-214.

49. Max Weber, "Science as a vocation," in H.H.Gerth and C. Wright Mills (tr. and eds.), From Max Weber: Essays in Sociology (New York: Galaxy, 1958), pp. 129-156. 
cultural continuity with the conventional faiths of the society in which it appears or originates; maintaining a medium level of tension with its surrounding environment; achieving effective mobilization with strong governance and a high level of individual commitment; attracting and maintaining a normal age and sex structure; occurring within a favourable ecology which exists as a relatively unregulated religious economy and weakened conventional faiths; maintaining dense internal network relations; resisting secularization; and socializing the young. ${ }^{50}$ Of these, only the fifth (occurring within a favourable ecology) is an exogenous factor with all the others endogenous. The $F L G$ has fulfilled almost all of the endogenous criteria, especially the first three. For the first two, the FLG retains continuity with the Confucian teachings on the one hand and makes some compromise with the commercialized culture on the other. While the FLG devaluates the increasingly materialistic culture, it never requires its followers to leave their ordinary social and economic lives. Its denial of modern medication, nevertheless, does put it in tension with its surrounding environment to a certain degree. For the third criterion, the mass sit-in in Zhongnanhai reveals the mobilization power of the FLG. The subsequent resistant actions and defiant struggles show the level of commitment of the core followers. For the only exogenous factor in Stark's model, it has been shown earlier that the socio-cultural environment in China in the early 1990s was favourable for cult-like religions to emerge. When the FLG is situated in Stark's model, the only obvious unfavourable ecological condition is the highly regulated religious economy in China. Nevertheless, it is unconvincing to suggest that it is simply the lack of religious freedom in China that led to the severe crackdown against it.

A more plausible cause for the CCP's suppression of the $F L G$ is its perception of the movement as a threat to its rule. Its perception is shaped by the interaction among the characteristics of the FLG, the actions of the $F L G$ followers, and the historical and political matrix in China.

The political implication of NRMs in Chinese history and the religious nature of the FLG. In Chinese history, anti-government rebellions almost always took the form of NRMs. For example, the fearsome rebellion of the Yellow Turbans in the Han Dynasty in 184 took the central authorities eleven months to suppress and resulted in 30-year internal wars and conflicts. Toward the end of the Yuan Dynasty, the White Lotus Sect revolted against the emperor and seized part of the empire. The sect revived in the 18th to the 19th century during the Qing Dynasty and caused turbulence in the empire. The semi-Christian Kingdom of Heavenly Peace in the middle of the Qing Dynasty was threatening to the state and led to 20 million deaths. ${ }^{51}$ The analysis above shows that the

50. Rodney Stark, "How religions succeed: a theoretical model," in The Future of New Religious Movements, p. 13.

51. Chun-ken Lui and Wing So, Zhongguo shijie lun: zongjiao fazhan pian (Chinese History Analysis: The Development of Religions) (Hong Kong: Dan Ching Publishers, 1998). 
$F L G$ is not a sect in its organization and would be unlikely to be as socially dangerous as any of the past religious movements. Nevertheless, it has its own ideology and organizational strengths. Its ability to mobilize thousands of protesters without the CCP knowing made it appear to be politically dangerous and comparable to other NRMs in the past.

The extremely orderly and disciplined manners of FLG petitioners outside the CCP leaders' residence on 25 April 1999 shocked the leaders. The petitioners did not hold placards or shout slogans, nor did they obstruct or occupy any part of the street. They stood close to one another in three or four rows along the street to maintain order and prevent outsiders from inserting themselves. Men in the foremost row faced the street. Those behind sat on the ground, some resting, others reading the Zhuan falun. If they were approached by journalists they generally refrained from giving any replies. After eating, they wrapped the rubbish in plastic bags and took them away when they left. They did not leave a single scrap of paper or a cigarette butt. ${ }^{52}$ The $F L G$ followers appeared to the CCP leaders to be "extraordinary." The leaders soon realized that this disciplined and orderly demeanour was associated with the religious or quasi-religious nature of the organization. One of the Party leaders called for immediate action to investigate the $F L G$ because:

We are now at a sensitive point in time, and similar incidents may very well produce certain mental associations in people's minds. We must pay close attention to various tendencies in society and nip the problem in the bud. Comrades, we must not, under any circumstances, underestimate the appeal of Falungong, an organization with a religious patina. ${ }^{53}$

Throughout Chinese history, secret societies and quasi-religious organizations prospered whenever society experienced too much dramatic change or rulers failed to soothe mass grievances. In late 1990s China, rising unemployment and income inequality were coupled with the risk of the CCP losing legitimacy. It did not require too much imagination to perceive the $F L G$ as a threatening religious movement that could disrupt, if not revolt against, the CCP's rule.

The authorities depicted the fight against the $F L G$ as a "serious ideological and political struggle." ${ }^{54}$ Li Hongzhi was said to have conspicuous political ambitions and instigated people to oppose the government:

Li Hongzhi's ulterior motive is to grab the ideological commanding heights from the Communist Party. He fabricated a whole set of absurd ideas, and made people believe

52. According to Zong Hairen, "Handling the falungong case" and various media reports. For example, see "10,000 protesters in Beijing urge cult's recognition," The New York Times, 26 April 1999) and "Followers line streets near Party headquarters in biggest demonstration since 1989," South China Morning Post, 26 April 1999.

53. Zong Hairen, "Handling the falungong case," p. 63.

54. "Getting a thorough grasp of the political nature of falun gong," a commentary article published by New China News Agency in Beijing, China Daily, 1 August 1999. See also "Li Hongzhi, a cult leader with evil political ambition," China Daily, 4 August 1999, and "More people clear on true nature of falun gong," China Daily. 15 August 1999). 
that his words were the only absolute truth in the world. His remarks on Heaven and God ... plainly reveal his aim of overthrowing materialism and the Communist Party. ${ }^{55}$

The State Planning Committee characterized the fight against the FLG as "an extremely complicated, life-or-death political struggle." 56 The political agenda and the power of the $F L G$ seem to be overstated by the CCP. However, they had grounds for this. The FLG appeared to be threatening to the rule of the CCP not only because of its religiously tinged attributes but also due to its efficiency in mobilizing mass action and its unique organization.

The canon of social stability and the mobilization power of the FLG. The CCP has been particularly sensitive about mass movement and collective action since the 1989 pro-democracy student movement. The political leaders might have different suggestions of how to handle the FLG mass sit-in, but they all agree that maintaining social stability is the highest interest of the country. ${ }^{57}$

FLG petitioners' effort to present a good image by being sober and disciplined in the mass sit-in turned out to be a fearful sign for the CCP. It showed how powerful the $F L G$ could be in organizing mass action and disciplining the participants. In addition, the FLG had staged over ten petitions to different mass media organizations to protest against their distorted reports about the group before the one it did in Zhongnanhai. A CCP leader noted that the Zhongnanhai sit-in "is the most serious political incident since the 'June 4' political disturbance in 1989."58

The high mobilization power of the FLG is related to its followers' strong ideological commitment and its organizational structure. The ideological commitment of the core followers to their charismatic leader in a sense resembles the ideological commitment of the masses to Mao in the 1950 s to the early 1970s. The resilience and self-discipline traits of the followers shown in various mass petitions all seem fearsome to the CCP leaders. In accusing the FLG of having a substantial political background, one of the CCP leaders made the following comments:

Think back to April 25 ten years ago, when the Central Television Station broadcast the People's Daily editorial on taking a clear-cut stand against bourgeois liberalism. Isn't it quite clear why they ( $F L G$ followers) have illegally converged on Zhongnanhai on the same day ten years later, at such a sensitive moment? ${ }^{59}$

Late April is indeed a sensitive moment as it also commemorates the

55. "Li Hongzhi's political motives and serious mischief: commentary," China Daily, 11 August 1999).

56. " 'Si Erwu' shijian zhenxiang gongbu gejie fanying qianglie: guangda ganbu qunzhong qiedi renqing falun gong xian'e zhengzhi yongxin" "'Strong reactions to the real picture of the "April 25' incident: the officials and the public should know about the evil political motive of the falun gong"), Renmin ribao (People's Daily), 16 August 1999.

57. Zong Hairen, "Handling the falungong case," pp. 57 and 65, citing Zhu Rongji and $\mathrm{Hu}$ Jintao's emphasis on social stability.

58. Ibid. p. 66.

59. Ibid. p. 63. 
student demonstration in Beijing on 27 April 1989 to pay tribute to $\mathrm{Hu}$ Yaobang's death.

It should be noted that a series of reactions between the $F L G$ and the CCP before the crackdown have made the FLG more political and the CCP more legitimated to clamp down on the group. Following the 25 April petition to Zhongnanhai, news of the collective demonstrations and petitions of $F L G$ followers was reported all over the country. ${ }^{60}$ And arrests of some of the FLG key members happened before the official ban on 22 July. ${ }^{61}$ On 26 June 1999, I attended a FLG international sharing conference in Chicago and observed that some core followers were discussing what the FLG could do in the face of the Chinese authorities' detention of their fellows. Some followers suggested that they could preach the FLG teachings to those in politics in the United States. They believed that if more and more American city mayors gave official recognition to Li Hongzhi, the FLG would become more legitimate and people would tend to disbelieve the CCP's accusations. After the incident of 25 April and the CCP's strong criticism of the group afterwards, the $F L G$ gave up their previous apolitical stance to defend their legitimation and to gain international sympathy and support. Li Hongzhi became a star for various news media. ${ }^{62}$ Overseas FLG followers' strategic move towards American politics and Li's exaggerated spotlighting of the group's global scale and influence certainly further embarrassed the CCP and reinforced its belief that the FLG was politically hazardous.

The organization of the FLG and the charismatic leader's overseas support. Before the crackdown, the FLG had 39 main stations, 1,900 guidance stations and 28,000 practices sites spread over China. ${ }^{63}$ The vertical point-to-point connection, together with a tightly knit cyber network and a dispersed interpersonal network, gave the FLG a unique, efficient internal organization which both facilitated its mass mobilization and made it difficult for the CCP to put it under surveillance. The Party leaders know how to deal with conventional organizations. But how could they deal with an invisible organization that has high mobilization power and an efficient internal network? Accordingly, Jiang Zemin was startled and angered when the Ministry of Public Security overlooked the FLG organization. ${ }^{64}$

The CCP was also alarmed by the involvement of numerous Party members and high officials in the FLG. According to Zong, 15.6 per cent of the officially announced 2.3 million FLG followers were Party members. ${ }^{65}$ Furthermore, functionaries of state organs, military people, armed police, medical practitioners, teachers and even diplomats were also

60. Ibid. p. 67.

61. Ibid. p. 69.

62. "Falun Buddhist method", Ming Pao, 11 May 1999.

63. Wong, "The mystery," p. 17.

64. Zong Hairen, "Handling the falungong case," pp. 60-61.

65. Ibid. p. 67. 
found in the $F L G .^{66}$ The Party leaders were bewildered when they found that the five $F L G$ representatives who requested a meeting with Zhu Rongji on 25 April came from the Ministry of Public Security, the Ministry of Inspection Supervision, the Ministry of Railways, the Second Department of the General Staff Headquarters and Beijing University. ${ }^{67}$

Another irritation to the CCP leadership was the charismatic leader's world-wide recognition and overseas support, particularly from North America. One of the top Party leaders voiced his worry over Li Hongzhi's overseas background soon after the 25 April mass sit-in: "The headquarters of Falungong and of Li Hongzhi are both in the United States. We must not exclude the possibility of organizations beyond our borders taking a hand in this matter."68 A few months later, the CCP accused the FLG leader of attempting to overthrow the Party and socialism with foreign backing:

It is a fact that Li Hongzhi used the Falun Gong organization to deliberately create chaos and undermine the good situation of stability and unity.... By ganging up with hostile forces abroad and at home, to overthrow the leadership of the Chinese Communist Party and change the socialist system. ${ }^{69}$

The charismatic leader, together with his family, emigrated to the United States in 1998. Since then, he has intensified his proselytizing activities overseas. In 1999, FLG main stations can be found in dozens of cities in North America, Eastern and Western Europe, Australia, South and Southeast Asia. ${ }^{70}$ As early as 1996, Li received honourable recognition from Houston, Texas. After FLG's mass sit-in in Beijing, Li received more official recognition in the United States. For example, the Mayor of the City of Chicago declared 25 June 1999 as "Master Li Hong Zhi Day in Chicago." Li also received official welcome and recognition letters from the cities of San Jose, Toronto and Ontario between May and July $1999 .^{71}$ Thus, it came as no surprise that $\mathrm{Li}$, who was a religious leader with millions of followers in China and had gained some sort of political support from North America, was perceived by the CCP as threatening to its rule.

\section{Conclusion}

From a sociological perspective, the $F L G$ is neither a sect nor a cult per se. It is, however, a NRM with cult-like characteristics. These are evidenced by its organizational structure, its relation to society and part of its belief content. The FLG emerged at a time when the economic system, social conditions and cultural values in China were undergoing

66. Ibid. p. 62.

67. Ibid. p. 55.

68. Ibid. p. 63.

69. "Fight falun gong to ensure stability," China Daily, 16 August 1999.

70. Information obtained from falun dafa official website.

71. Information obtained from my field observation of the Experience Sharing Conference in Chicago on 26 June 1999. It is also posted on the falun dafa website. 
drastic changes. These changes provided a favourable ecological condition for the FLG and other religious and quasi-religious movements to emerge and expand in the last two decades in China. The FLG and other similar groups emerged as a response to unresolved secular problems, a normative breakdown and an ideological vacuum in China.

The majority of the FLG practitioners were initially drawn to the $F L G$, as to other quasi-religious qigong groups, for health improvement. However, some people found the FLG different from the others because it provided them with a set of moral standards and guidance; others found it capable of explaining unexplained human puzzles, particularly the meaning of life and the mysteries of the universe.

The $F L G$ as a NRM itself is successful. It fulfils most of the criteria for success in Stark's model. It has a layer of ideologically committed core followers, a well-connected internal network, high mobilization capacity, effective organizational power and overseas support. It could have achieved its political goals if it operated in a different historical and political context. Nevertheless, the FLG began to decline in China after it demonstrated to the state authorities its mobilization and organizational power. The crackdown on the FLG cannot be attributed to either exogenous or endogenous factors alone. What is critical is the interplay between these two sets of factors. The Chinese history of religious movements and the political signification of mass movements have set up a peculiar context in which the more successful and large-scale a movement is, the more likely it is to face suppression. This is especially so when a movement is religious in nature with high mobilization power and invisible, well-connected networking.

The FLG is one of the many religious and quasi-religious qigong movements that arose in China during a period of rapid economic and social changes. My findings on the popularity of the FLG accord with various sociological explanations for the emergence of the NRMs in Euro-American contexts. Nevertheless, the case of the FLG also shows the inadequacy of applying Euro-American sociological theories squarely to non-Euro-American contexts. The concepts of sect and cult, for example, developed out of a specific Judeo-Christian historical and socio-cultural context. Similarly, an exemplary theory of successful NRMs in the United States cannot be applied unreservedly in a Chinese context without taking its political and historical factors into consideration. This may hold true when we apply any other social science theories developed in the West to the case of China. 